\title{
Internet Drugiej Generacii dla bibliotek i ich użytkowników
}

DOI: http://dx.doi.org/10.12775/TSB.2016.014

STRESZCZENIE: Zastosowanie narzędzi Web $2.0 \mathrm{w}$ działalności wielu instytucji jest już od kilku lat trendem. Wykorzystują go również biblioteki, w których wspomaga on realizację ich podstawowych zadań oraz stanowi istotny element na drodze zaspokajania potrzeb ich użytkowników. Odpowiedź na pytanie, w jaki sposób i na jakich płaszczyznach instrumenty Web 2.0 znajdują swoje zastosowanie w bibliotekach, przynosi książka Marty Tyszkowskiej pt. Jak korzystać z Web 2.0 w każdej bibliotece? Niniejszy artykuł zawiera omówienie tego wydawnictwa. Recenzowana praca składa się z czterech rozdziałów. Rozdział pierwszy poświęcony został koncepcji Internetu Drugiej Generacji. Rozdział drugi dotyczy obecności Internetu Drugiej Generacji w bibliotekach i wykorzystania koncepcji Biblioteki 2.0 na gruncie polskim. Trzecia część pracy obejmuje krytyczną analizą zjawiska Web 2.0 i próbę określenia konsekwencji jego rozwoju na szeroką skalę. W ostatnim rozdziale zostały omówione poszczególne narzędzia Web 2.0.

SŁoWA KLUCzowE: Biblioteka 2.0, Web 2.0, Web 2.0 w bibliotekach. \footnotetext{
¿ yjemy obecnie w galaktyce Internetu, która wyparła galaktykę
„Gutenberga” - takimi słowami socjologa Manuela Castellsa Marta

* Uczestniczka studiów doktoranckich z zakresu bibliologii prowadzonych na Wydziale Nauk Historycznych Uniwersytetu Mikołaja Kopernika w Toruniu.
} 
Tyszkowska, autorka książki pt. Jak korzystać z Web 2.0 w każdej bibliotece?, wskazuje, że Internet coraz częściej zajmuje obszar społeczno-organizacyjny w życiu ludzi oraz gwarantuje im dodatkowo różnorodne rozwiązania i narzędzia możliwe do zastosowania na tej płaszczyźnie. Konsekwencją tego jest powstanie Sieci Drugiej Generacji (Web 2.0), której autorka poświęca cztery rozdziały książki, prezentujące kolejno koncepcje Web 2.0, kontrowersje wokół jego narzędzi, ich charakterystykę wraz z funkcjami oraz zastosowania założeń Internetu Drugiej Generacji w bibliotekach.

Celem omawianego wydawnictwa jest „ukazanie koncepcji Internetu Drugiej Generacji dla współczesnych bibliotek oraz ich użytkowników"1. Autorka zwraca uwagę, że biblioteki zgodnie ze swoimi podstawowymi zadaniami, a także wychodząc naprzeciw oczekiwaniom ich użytkowników, powinny stosować rozwiązania i narzędzia Web 2.0, ponieważ - jak słusznie wskazuje M. Tyszkowska - wpływają one na funkcjonowanie tych instytucji kultury.

W pierwszym rozdziale autorka książki podejmuje próbę szczegółowego opisu rozwoju Internetu oraz zaprezentowania szerokiej charakterystyki zjawiska Web 2.0. Wskazanie związków powstania, opis sieci komunikacyjnej oraz jej przekształcenia w sieć Internet, a następnie projektowania i wdrażania różnorodnych narzędzi od e-mail, poprzez WAP (ang. Wireless Application Protocol) aż do języków programowania, umożliwiło autorce płynne przejście do wskazania punktu wykształcenia się Internetu Drugiej Generacji. Warte i cenne uwagi są przytoczone w tym miejscu książki dane dotyczące przyrostu portali internetowych, serwerów i użytkowników sieci oraz portali społecznościowych, które mogą uświadomić czytelnikom skalę użytkowania przez populację sieci Web 2.0. W rozdziale pierwszym nie brak dyskursu terminologicznego, podania pierwszego użycia terminu Web 2.0 oraz dokładnego wskazania i objaśnienia różnic pomiędzy nim a mediami społecznościowymi autorka sama wspomina, że obydwa pojęcia są dość często zamiennie stosowane. Charakterystyka zjawiska Web 2.0 została przygotowana w oparciu o określenia terminu zaczerpnięte z bogatej literatury zagranicznej, klasyfikacje mediów społecznościowych według Dominika

1 M. Tyszkowska, Jak korzystać z Web 2.0 w każdej bibliotece?, Warszawa 2015, s.10. 
Kaznowskiego, Andreasa Kaplana i Michaela Haenleina, Liany Evans i Jarosława Roszkowskiego, opisy cech charakterystycznych i aspekty społecznego charakteru Web 2.0 - grup wirtualnych społeczności. W rozdziale pierwszym autorka znalazła także płaszczyznę do omówienia kwestii kultury konwergencji.

Dalsza część publikacji poświęcona jest ukazaniu wpływu środowiska Web 2.0 na biblioteki i przedefiniowaniu ich roli na skutek wprowadzenia w pewne obszary działalności tych instytucji narzędzi Web 2.0. Rozdział drugi rozpoczyna charakterystyka Biblioteki 2.0, zjawiska będącego klasycznym przejawem Web 2.0. Autorka sama wskazała na początku swojej pracy, przytaczając licznie nazwiska badaczy, że dotychczas opublikowano wiele publikacji dedykowanych specyfice Biblioteki Drugiej Generacji. Niewątpliwe w dalszych podrozdziałach - odmiennie od innych charakterystyk Biblioteki 2.0 zawartych w literaturze - autorka skupia się na roli bibliotekarza, wskazując „Manifest Bibliotekarza 2.0”, oraz kwestiach kształcenia bibliotekarzy z wykorzystaniem Web 2.0 w przyszłości. Zastosowany dobór treści kształcenia autorka szczegółowo objaśnia. Jedyną wątpliwość budzą zaprezentowane wyniki badań z 2009 r. poświęcone wykorzystywaniu narzędzi Web 2.0 przez nauczycieli akademickich. Sześć lat, jakie upłynęły od przeprowadzonego badania do wydania książki M. Tyszkowskiej, szczególnie w sferze narzędzi Internetu, jest okresem ogromnego postępu technologicznego w zakresie dostępności narzędzi, jak i świadomości społeczności akademickich co do możliwości wykorzystywania Internetu Drugiej Generacji w procesach kształcenia. Lawinowy rozwój badań w zakresie wykorzystania narzędzi Internetu przez pracowników naukowych w ciągu ostatnich sześciu lat pozbawia więc wartości naukowej przytaczanych wyników badań. Cenne jest natomiast omówienie takich aspektów, jak: z czym się wiąże, jakie skutki niesie i jakie obowiązki nakłada na pracowników bibliotek

2 „Manifest Bibliotekarza 2.0” to zestaw 17 cech przygotowanych przez Laurę Cohen. Przykładami takich cech są m.in. dostrzeganie szybkich zmian świata kultury informacji, zauważanie zmian wolnej przemiany bibliotek i wraz z kolegami pracowanie nad tym, czy tworzenie otwartych stron WWW umożliwiających dołączenie użytkowników do bibliotekarzy w celu wymiany doświadczeń i ulepszenia procesów uczenia się. M. Flipczak, Jak daleko stąd do nowoczesności - w stronę biblioteki drugiej generacji. „Biuletyn EBIB” [online] 2008, nr 1 (92) [dostęp 31 maja 2016]. Dostępny w World Wide Web: http:// www.ebib.pl/2008/92/a.php?filipczak. 
stosowanie narzędzi Web 2.0 oraz zwrócenie uwagi na problemy z tego wynikające.

Trzecia - najkrótsza - część recenzowanego wydawnictwa poświęcona jest kontrowersjom wynikającym ze stosowania narzędzi Web 2.0. Autorka prezentuje tu konsekwencje szerokiego rozwoju Internetu Drugiej Generacji, za które uznaje problemy lekkiego traktowania kultury i obniżenia poziomu informacji w mediach Web 2.0, manipulacji, kłamstw poprzez Sieć 2.0, komercyjne wykorzystywanie treści tworzonych i udostępnianych przez użytkowników sieci wraz z problemami autorsko-prawnym tychże materiałów. Opisy tych zjawisk autorka oparła na czterech aspektach: naukowym, kulturowym, prawnym i ekonomicznym. Przyjęte przez autorkę opisy zjawiska Web 2.0 w kontekście czterech aspektów trafnie przedstawiają złożoność omawianego w trzecim rozdziale zjawiska.

Szczególne miejsce w pracy autorka poświęca narzędziom Web 2.0, które niejednokrotnie wykorzystywane są w polskim środowisku bibliotekarskim, choć na początku ostatniego, czwartego rozdziału książki nie doprecyzowano, o pracownikach których typów bibliotek jest tu konkretnie mowa. Struktura tego rozdziału oparta jest na funkcjach stosowanych w narzędziach Internetu Drugiej Generacji, jak i samych narzędziach. Swoje rozważania M. Tyszkowska rozpoczyna od serwisów społecznościowych. Poczynając od ich definicji, w dalszej kolejności prezentuje ich funkcje, powołując się na ustalenia Pawła Frankowskiego. W dalszej części podrozdziału M. Tyszkowska przywołuje kalendarium powstałych dotychczas kilku wybranych serwisów oraz je omawia. Charakterystyka ta objętością przewyższa fragmenty poświęcone kluczowemu wątkowi omówieniu zastosowania serwisów w społeczności bibliotekarskiej. W podrozdziale drugim autorka charakteryzuje i objaśnia mechanizmy wiki oraz ukazuje etymologię tego określenia. W tym miejscu prezentuje oprogramowanie wykorzystywane do tworzenia platform wiki oraz omawia serwisy Wikipedia oraz LibraryWiki. Autorka dostrzega celowość tworzenia serwisów opartych na mechanizmach wiki, o czym nie zapomina wspomnieć na końcu podrozdziału.

Odmiennie od pierwszych dwóch podrozdziałów rozdziału czwartego, w podrozdziale trzecim M. Tyszkowska, omawiając blogi i wskazując ich funkcji oraz rodzaje, przytacza praktyczne aspekty przydatne w stosowaniu tego rodzaju narzędzi oraz wymienia obszary, w jakich mogą 
one służyć środowisku bibliotekarskiemu. W tym podrozdziale autorka przytacza także nazwiska polskich bibliologów i bibliotekoznawców piszących blogi, dowodząc tym samym, że narzędzie to jest już stosowane $\mathrm{w}$ tym środowisku.

Cenne w tej części pracy jest zwrócenie uwagi na folksonomię, tj. wyjaśnienie takich aspektów społecznościowego tagowania, jak typologie tagów, motywacje tagowania, cechy charakterystyczne tagowania, zalety, wady i trudności stosowania tagów w bibliotekach. W dalszych podrozdziałach książki M. Tyszkowskiej nie brak także omówienia innych narzędzi Web 2.0, tj. kanałów RSS, komunikatorów internetowych, list i forów dyskusyjnych, podcastów i wideocastów, społecznościowych katalogów bibliotecznych. Podchodząc krytycznie do zawartości rozdziału czwartego, należy zauważyć dysproporcję treści w poszczególnych podrozdziałach, widoczną zwłaszcza pomiędzy ilością rozważań poświęconych prezentacji samych narzędzi i ich funkcji a opisem ich zastosowania w instytucjach kultury, głównie odbiorców książki.

Objętość książki to zaledwie 99 stron, na łamach których autorka wyraźnie zastosowała interdyscyplinarne podejście, skorzystała z wielu źródeł z zakresu biznesu, marketingu, a także informatyki oraz bibliotekarstwa, bazując przede wszystkim na materiałach obcojęzycznych. Mimo że publikacja M. Tyszkowskiej nie podejmuje nowego tematu z zakresu bibliotekoznawstwa, bo sama koncepcja Web 2.0, jak i Biblioteki 2.0 była już zagadnieniem poruszanym na łamach wielu fachowych artykułów i książek ${ }^{3}$, stanowi ona dobrą propozycję dla pracowników wszystkich rodzajów bibliotek, którzy dzięki niej mogą dowiedzieć się, jak lepiej zaspokajać oczekiwania swoich użytkowników. W tym kontekście przydzielenie tej publikacji do serii wydawniczej Wydawnictwa Stowarzyszenia Bibliotekarzy Polskich „Propozycje i Materiały” jest dobrym odzwierciedleniem przeznaczenia książki, której walorem jest również prosty język wypowiedzi.

3 Na przykład artykuły i książki Grzegorza Gmiterka, jak choćby Biblioteka 2.0. Biblioteka w środowisku społecznościowego Internetu, Warszawa 2012. 


\section{Bibliografia}

Flipczak Małgorzata, Jak daleko stąd do nowoczesności - w stronę biblioteki drugiej generacji. „Biuletyn EBIB” [online] 2008, nr 1 (92) [dostęp 31 maja 2016]. Dostępny w World Wide Web: http://www.ebib.pl/2008/92/a. php?filipczak.

Gmiterek Grzegorz, Biblioteka 2.0. Biblioteka w środowisku społecznościowego Internetu, Warszawa 2012.

Tyszkowska Marta, Jak korzystać z Web 2.0 w każdej bibliotece?, Warszawa 2015.

\section{Web 2.0 for Libraries and their Users}

ABstract: The use of Web 2.0 tools in the activities of many institutions is the trend today. The libraries use its tools and solutions to realize their basic tasks and as an important element in the way of meeting the needs of their users. The use of the Web 2.0 concept and its influence for modern libraries and their users is the intention of the book of Marta Tyszkowska Jak korzystać z Web $2.0 \mathrm{w}$ każdej bibliotece? (How to use Web 2.0 in every library?). The article includes a review of this book. The reviewed work consists of four chapters. The first chapter was devoted to the concept of We 2.0. The second chapter refers to the presence of the Web 2.0 in libraries and use the concept of Library 2.0 on Polish soil. The third part of the work includes a critical analysis of the phenomenon of Web 2.0 and attempt to determine the consequences of its development on a large scale. The last chapter discusses the various tools of Web 2.0.

KEYWORDS: Library 2.0, Web 2.0, Web 2.0 for libraries. 